\title{
Numerical Model Description of Fibres Winding Process for New Technology of Winding Fib- res on the Frames
}

Michal Petru, Tomas Martinec, Jaroslav Mlynek

Technical University of Liberec, Studentská 2, 461 17, Liberec 1, Czech Republic. E-mail: michal.petru@tul.cz, tomas.martinec@tul.cz, jaroslav.mlynek@tul.cz

Currently, traditional materials are very often replaced by composite materials in many industrial areas. The advantages of these materials consist mainly in their lightweight, high strength and flexibility, corrosion resistance and a long lifespan. The use of composites reaches its large development in the field of aerospace. This article discusses quality of the manufacturing process technology of a specially shaped composite frame in 3D space. The used technology is based on a winding of carbon, glass, organic filament rovings on a polyurethane core. Polyurethane core which is a geometry of frame with and without a circular cross section. Quality production of said type of composite frame depends primarily on the correct winding of fibers on a polyurethane core. It is especially needed to ensure the correct angles of the fibers winding on the polyurethane core and the homogeneity of individual winding layers. The quality of fibers winding also depends on the material properties of polyurethane core and fibers. The article describes mathematical model for use an industrial robot in filament winding and how to calculate the trajectory of the robot. When winding fibers on the polyurethane core which is fastened to the robotend-effector so that during the winding process goes through a fibre-processing head on the basis of the suitably determined robot-end-effector trajectory. We use for description numerical model and matrix calculus to enumerate the trajectory of the robot-end-effector to determine the desired passage of the frame through the fibre-processing head. The calculation of the trajectory was programmed in the Delphi development environment. Equations and relations of the numerical model are important for use a real solving of the passage of a polyurethane core through fibre-processing head.

Keywords: Numerical model, composite materials, technology of winding fibers, Denavit-Hartenberg method

\section{Acknowledgements}

The results of this project No. LO1201 were obtained through the financial support of the Ministry of Education, Youth and Sports, Czech Republic in the framework of the targeted support of the "National Programme for Sustainability I".

\section{References}

[1] RUSNAKOVA, S., ZALUDEK, M., BAKOSOVA, D. (2012). Processing engineering of large composites structures using low-pressure vacuum infusion. In: Manufacturing Technology, Vol. 12, June 2012, pp. 83-86.

[2] NOVAKOVA-MARCINCINOVA, L., NOVAK-MARCINCIN, J. (2014). Production of abs-aramid composite material by fused deposition modeling rapid prototyping system. In: Manufacturing Technology, Vol. 14, N.1, pp. 85-91.

[3] SCIAVICCO, L., SICILIANO, B. (2004). Modelling and Control of Robot Manipulators, p.378. Springer, London.

[4] JAZAR R., N. (2004). Theory and applied robotics, p.883. Springer, New York.

[5] SCIAVICCO, L., SICILIANO, B. (2004). Modelling and Control of Robot Manipulators, p.378. Springer, London.

[6] MARTINEC T, MLÝNEK J, PETRŮ, M. (2015). Calculation of the robot trajectory for the optimum directional orientation of fibre placement in the manufacture of composite profile frames, Robotics and Computer-Integrated Manufacturing, Vol. 35, pp. 42-54.

[7] SEVCIK, L., LEPSIK, P., PETRŮ, M., MAŠ́́IN, I., MARTONKA, R. (2014). Modern Methods of Construction Design, Lecture Notes in Mechanical Engineering, p. 631. Springer.

[8] BALOČKOVÁ, L. (2013). The method for solving kinematics of an industrial robot, In:Applied Mechanics and materials, Vol. 283, pp. 279-281.

[9] MÜLLER, M., VALÁŠEK, P. (2014). Optimization of Surface Treatment of Carbon Steel in Area of Adhesive Bonding Technology with Application of Quik-Setting Adhesives. In: Manufacturing Technology, Vol. 14 N.4, pp. 579-584. 
[10] KUMIČÁKOVÁ, D., GÓRSK, F., MILECKI, A., GRAJEWSKI, D. (2013). Utilization of Advanced Simulation Methods for Solving of Assembly Processes Automation Partial Tasks. In: Manufacturing Technology, Vol. 13, N. 4, pp. 478-486.

[11] ŽMINDÁK, M., PELAGIĆ, Z., SOUKUP, J. (2015). Analysis of Fiber Orientation Influence to Dynamic Properties of Composite Structures. In: Manufacturing Technology, Vol. 15, N. 3, pp. 490-494.

\section{Paper number: M2016145}

Copyright $($ C) 2016. Published by Manufacturing Technology. All rights reserved. 